\title{
IGF-I regulates pro-opiomelanocortin and GH gene expression in the mouse pituitary gland
}

\author{
J Honda, Y Manabe, R Matsumura, S Takeuchi and S Takahashi \\ Department of Biology, Faculty of Science, Okayama University, Tsushima, Okayama 700-8530, Japan \\ (Requests for offprints should be addressed to S Takahashi; Email: stakaha@cc.okayama-u.ac.jp)
}

\begin{abstract}
IGF-I is expressed in somatotrophs, and IGF-I receptors are expressed in most somatotrophs and some corticotrophs in the mouse pituitary gland. Our recent study demonstrated that IGF-I stimulates the proliferation of corticotrophs in the mouse pituitary. These results suggested that somatotrophs regulate corticotrophic functions as well as somatotrophic functions by the mediation of IGF-I molecules. The present study aimed to clarify factors regulating pituitary IGF-I expression and also the roles exerted by IGF-I within the mouse anterior pituitary gland. Mouse anterior pituitary cells were isolated and cultured under serum-free conditions. GH $(0.5$ or $1 \mu \mathrm{g} / \mathrm{ml})$, ACTH $\left(10^{-8}\right.$ or $\left.10^{-7} \mathrm{M}\right)$, GH-releasing hormone (GHRH; $10^{-8}$ or $10^{-7} \mathrm{M}$ ), dexamethasone (DEX; $10^{-8}$ or $\left.10^{-7} \mathrm{M}\right)$ and estradiol-17 $\beta\left(\mathrm{E} 2 ; 10^{-11}\right.$ or $\left.10^{-9} \mathrm{M}\right)$ were given for $24 \mathrm{~h}$. IGF-I mRNA levels were measured using competitive RT-PCR, and GH and proopiomelanocortin (POMC) mRNA levels were measured using Northern blotting analysis. GH treatment significantly increased IGF-I mRNA levels (1.5- or $2 \cdot 1$-fold).
\end{abstract}

ACTH treatment did not alter GH and IGF-I mRNA levels. IGF-I treatment decreased GH mRNA levels $(0 \cdot 7-$ or $0 \cdot 5$-fold), but increased POMC mRNA levels $(1 \cdot 8-$ fold). GH treatment (4 or $8 \mu \mathrm{g} / \mathrm{ml}$ ) for 4 days increased POMC mRNA levels. GHRH treatment increased GH mRNA levels (1·3-fold), but not IGF-I mRNA levels. DEX treatment significantly decreased IGF-I mRNA levels $(0 \cdot 8$-fold). E2 treatment did not affect IGF-I mRNA levels. GH receptor mRNA, probably with GHbinding protein mRNA, was detected in somatotrophs, and some mammotrophs and gonadotrophs by in situ hybridization using GH receptor cDNA as a probe. These results suggested that IGF-I expression in somatotrophs is regulated by pituitary GH, and that IGF-I suppresses GH expression and stimulates POMC expression at the transcription level. Pituitary IGF-I produced in somatotrophs is probably involved in the regulation of somatotroph and corticotroph functions.

Journal of Endocrinology (2003) 178, 71-82

\section{Introduction}

Insulin-like growth factor-I (IGF-I) is a 70 amino acid polypeptide that is produced in a number of tissues. Several reports have shown that IGF-I regulates the proliferation and differentiation of various cells in an autocrine and/or paracrine manner. Pituitary cells synthesize IGF-I (Fagin et al. 1988, Gonzalez-Parra et al. 2001), and express IGF-I receptors (Bach \& Bondy 1992). Our previous study showed that IGF-I is expressed in somatotrophs, and that type I receptors for IGF-I are expressed in somatotrophs and some corticotrophs in the mouse pituitary (Honda et al. 1998). We recently demonstrated that IGF-I stimulated the proliferation of anterior pituitary cells, in particular corticotrophs, indicating that the proliferation of anterior pituitary cells was stimulated by IGF-I produced in the anterior pituitary cells (Oomizu et al. 1998). In addition, there are many reports showing that IGF-I regulates GH expression and secretion at the pituitary level (Goodyer et al. 1984a, Yamashita \& Melmed 1986) and/or the hypothalamic level (Abe et al. 1983, Tannenbaum et al. 1983). These findings suggested that pituitary IGF-I regulates the functions of corticotrophs and somatotrophs. However, there are few reports about the effects of IGF-I on adrenocorticotropic hormone (ACTH) secretion, although Goodyer et al. (1984a) reported that ACTH release remained unaltered with IGF-I treatment. Therefore, the aim of the present study was to clarify the role of IGF-I on mouse pituitary corticotrophs as well as somatotrophs.

It is necessary to study the regulatory mechanism for pituitary IGF-I expression in order to understand the physiological roles of IGF-I within the pituitary gland. Pituitary IGF-I synthesis is thought to be dependent on growth hormone $(\mathrm{GH})$, based on reports that pituitary IGF-I gene expression is enhanced in GH-secreting tumor-bearing rats relative to control animals (Fagin et al. 1988), and that GH treatment increases IGF-I mRNA 
levels in pituitary tumor $\mathrm{GH}_{3}$ cells (Fagin et al. 1989). In the present study, we studied the effects of $\mathrm{GH}$, estradiol$17 \beta$ (E2), ACTH, GH-releasing hormone (GHRH) and dexamethasone (DEX) treatment on IGF-I expression in mouse pituitary cells in vitro. We used a competitive RT-PCR assay with heterologous sequence cDNA competitors to measure the low levels of IGF-I mRNA expression in cultured mouse pituitary cells. GH receptor mRNA-expressing cells were analyzed by non-radioisotopic in situ hybridization, and their hormone content was analyzed by immunofluorescence microscopy.

In this study, we have demonstrated a stimulatory effect of IGF-I on pro-opiomelanocortin (POMC) gene expression and an inhibitory effect on GH gene expression in mouse pituitaries. Somatotrophs are the main source of pituitary IGF-I. We have also shown a stimulatory effect of GH on IGF-I gene expression. These findings provide insights into the interaction between somatotrophs and corticotrophs mediated by IGF-I that may be one example of an intrapituitary regulatory system.

\section{Materials and Methods}

\section{Animals}

Male ICR mice (CLEA Japan Inc., Osaka, Japan) were kept in a temperature-controlled animal room with free access to commercial diet CE-7 (CLEA Japan Inc.) and tap water ad libitum. All animal care and experiments were carried out according to the Guidelines for Animal Experimentation, Faculty of Science, Okayama University, Japan, and the NIH Guidelines for the Care and Use of Laboratory Animals.

\section{Culture}

Anterior pituitaries from 2-month-old male mice were dissociated with trypsin $(0.5 \%(\mathrm{w} / \mathrm{v})$; DIFCO, Detroit, MI, USA) as previously described (Oomizu et al. 1998). Cell viability was checked using the trypan blue exclusion test and was usually found to be more than $95 \%$. The isolated pituitary cells were suspended in a 1:1 mixture of Dulbecco's modified Eagle's medium and Ham's F12 medium (DMEM/F12) without phenol red (Sigma Chemical Co., St Louis, MO, USA) containing heatinactivated fetal calf serum (10\% (v/v); Gibco BRL, Life Technologies Inc., Rockville, MD, USA). The cells were seeded on poly-L-lysine (Sigma Chemical Co.)-coated 6-well tissue culture plates (Becton Dickinson, Lincoln Park, NJ, USA) at a density of $1 \times 10^{6}$ cells $/ 2 \mathrm{ml}$ per well for RNA measurement, and on poly-L-lysine-coated glass coverslips (diameter $13 \mathrm{~mm}$; Matsunami Glass Ind., Osaka, Japan) in 24-well tissue culture plates (Becton
Dickinson) at a density of $1 \times 10^{5}$ cells $/ 1 \mathrm{ml}$ per well for the detection of DNA synthesis. These cells were cultured in DMEM/F12 medium containing 10\% fetal calf serum for 1 day, and in serum-free DMEM/F12 medium

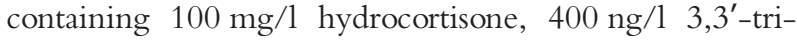
iodothyronine, $10 \mathrm{mg} / \mathrm{l}$ transferrin, $10 \mathrm{ng} / \mathrm{l}$ bovine glucagon, $200 \mathrm{ng} / 1$ parathyroid hormone and $5 \mathrm{mg} / 1$ sodium selenite for 3 days. All supplements were obtained from Sigma Chemical Co. Culturing was performed in a humidified incubator with $5 \% \mathrm{CO}_{2}$ and $95 \%$ air at $37^{\circ} \mathrm{C}$. The culture was allowed to proceed in a humidified atmosphere of $5 \% \mathrm{CO}_{2}$ and $95 \%$ air at $37^{\circ} \mathrm{C}$.

\section{Hormone treatment}

After a 3-day culture in serum-free DMEM/F12 medium, cultured cells were treated with rat GH $(0.5$ or $1 \mu \mathrm{g} / \mathrm{ml}$; NIDDK-rGH-B-11; NIH, Bethesda, MD, USA), rat ACTH $\left(10^{-8}\right.$ or $10^{-7} \mathrm{M}$; Sigma Chemical Co.), rat GHRH $\left(10^{-8}\right.$ or $10^{-7} \mathrm{M}$; Sigma Chemical Co.), E2 $\left(10^{-11}\right.$ or $10^{-9} \mathrm{M}$; Sigma Chemical Co.), DEX $\left(10^{-8}\right.$ or $10^{-7} \mathrm{M}$; Sigma Chemical Co.), and human recombinant IGF-I $(7.5$ or $75 \mathrm{ng} / \mathrm{ml}$; Amersham Pharmacia Biotech, Uppsala, Sweden) for $24 \mathrm{~h}$ followed by RNA extraction.

In a separate experiment, cultured cells were treated with rat GH (4 or $8 \mu \mathrm{g} / \mathrm{ml}$; NIDDK-rGH-B-11) for 4 days followed by RNA extraction. The medium supplemented with GH was exchanged every 2 days during the hormone treatment.

\section{Primers and competitors}

Primers for mouse IGF-I, mouse GH receptor and mouse $\beta$-actin were designed based on previous reports (Smith et al. 1988, Ho et al. 1995, Matsuda \& Mori 1997). The sequences of the primers are as follows: IGF-I 5' sense primer; 5'-GGACCAGAGACCCTTTGCGGGG3', IGF-I 3' antisense primer; 5'-GGCTGCTTTTGT AGGCTTCAGTGG-3', GH receptor $5^{\prime}$ sense primer; 5'-TTAGTTTGACCGGGATTCGTGG-3', GH receptor $3^{\prime}$ antisense primer; $5^{\prime}$-AATCTTTGGAACTGGGA CTGGG- $3^{\prime}, \beta$-actin $5^{\prime}$ sense primer; $5^{\prime}$-TCTAGACTT CGAGCAGGAGATGGCC- $3^{\prime}, \quad \beta$-actin $3^{\prime}$ antisense primer; 5'-CTAGAAGCACTTGCGGTGCACGATG$3^{\prime}$. These primers were expected to generate cDNAs of 210,437 and $471 \mathrm{bp}$ for IGF-I, GH receptors and $\beta$-actin respectively. All primers were synthesized by Gibco BRL Custom Primers (Life Technologies Oriental, Inc., Tokyo, Japan).

Competitors of IGF-I and $\beta$-actin were constructed using a competitive DNA construction kit (Takara Shuzo Co. Ltd, Otsu, Japan). The competitors contained heterologous $\lambda$ DNA sequences including primer sequences of IGF-I or $\beta$-actin at both ends. Using the 
competitors, the primers of IGF-I and $\beta$-actin generated PCR products of 346 and $550 \mathrm{bp}$ respectively.

\section{Competitive RT-PCR}

Total RNA was prepared from the cultured pituitary cells using the method of Chomczynski \& Sacchi (1987). Total RNA $(1 \mu \mathrm{g})$ in a final volume of $20 \mu \mathrm{l}$ was subjected to RT reaction using a SuperScript preamplification system for first strand cDNA synthesis (Life Technologies Oriental, Inc.) with oligo(dT) $)_{12-18}$ primers according to the manufacturer's instructions. In all RNA samples without the RT reaction, no amplified products were detected in the following PCR amplification, indicating no contamination of genomic DNA (data not shown).

A competitive RT-PCR assay was developed according to a previously established method (Kirk et al. 1994). One microliter of the RT samples from the cultured pituitary cells was used in one reaction of competitive RT-PCR with a series of dilutions of the competitors (for IGF-I, $10^{5}$, $5 \times 10^{5}$ and $10^{6}$ copies; for $\beta$-actin, $10^{7}, 5 \times 10^{7}$ and $10^{8}$ copies). The competitive RT-PCR for GH-treated and E2-treated samples was carried out using AmpliTaq Gold DNA polymerase (Applied Biosystems, Branchburg, NJ, USA) and a thermal cycler, Gene Amp PCR System 9600 (Applied Biosystems). The conditions for the PCR were as follows: after activation of the DNA polymerase by incubating for 9 min at $95{ }^{\circ} \mathrm{C}, 40$ cycles of reactions including denaturation for $30 \mathrm{~s}$ at $95^{\circ} \mathrm{C}$ and extension for $1 \mathrm{~min}$ at $60{ }^{\circ} \mathrm{C}$ were carried out, followed by additional extension for $10 \mathrm{~min}$ at $60^{\circ} \mathrm{C}$. The competitive RT-PCR for ACTH-treated, GHRH-treated and DEX-treated samples was carried out using TaKaRa Taq (Takara Shuzo Co. Ltd) and a thermal cycler, Gene Amp PCR System 9700 (Applied Biosystems). The conditions for the PCR were as follows: incubating for $10 \mathrm{~s}$ at $95{ }^{\circ} \mathrm{C}, 40$ cycles of reactions including denaturation for $30 \mathrm{~s}$ at $95^{\circ} \mathrm{C}$ and extension for $1 \mathrm{~min}$ at $60{ }^{\circ} \mathrm{C}$ were carried out, followed by additional extension for $10 \mathrm{~min}$ at $60^{\circ} \mathrm{C}$.

Ten microliters of PCR product were electrophoresed on $2.0 \%(\mathrm{w} / \mathrm{v})$ agarose gel, stained with ethidium bromide, photographed under ultraviolet illumination, and compared with a known standard, 100 bp DNA ladder (Life Technologies Oriental Inc.) for size determination. The band intensities were quantified by NIH Image (version 1.61). The log ratio between the band intensity of RT samples and that of the competitor was plotted against the concentrations of the competitors. The amount of the competitors required to give a 1:1 molar ratio of sample and competitor PCR products was then determined graphically. This gives a measure of IGF-I mRNA levels contained in the samples. $\beta$-Actin mRNA levels were used as an internal control according to previous studies (Fan et al. 1995, Chesnokova \& Melmed 2000, Fiorentini et al. 2002), and IGF-I mRNA levels were normalized relative to the amount of $\beta$-actin mRNA.
Northern blotting analysis

Northern blotting analysis was carried out according to the method described by Takeuchi et al. (1988) with slight modifications. Six micrograms of total RNA, prepared from the cultured pituitary cells using the method of Chomczynski \& Sacchi (1987), were denatured at $65^{\circ} \mathrm{C}$ for $15 \mathrm{~min}$ in $50 \% \quad(\mathrm{v} / \mathrm{v})$ formamide $-6.5 \% \quad(\mathrm{w} / \mathrm{v})$ formaldehyde-MOPS buffer (20 mM 3-(N-morpholino)2-hydroxypropanesulfonic acid, $8 \mathrm{mM}$ sodium acetate, $1 \mathrm{mM}$ EDTA, pH 7.0), and electrophoresed in a $6.5 \%$ $(\mathrm{w} / \mathrm{v})$ formaldehyde-1\% (w/v) agarose gel in MOPS buffer. The RNA was electrophoretically transferred to a nylon membrane (Hybond-N+; Amersham Pharmacia Biotech) at $4{ }^{\circ} \mathrm{C}$ overnight.

Mouse POMC cDNA (pcrmPOMC-JH1) and mouse GH receptor cDNA clone (pmghr1-1), both obtained by RT-PCR and subcloned into a vector pGEM3Zf $(+)$ and sequenced in our laboratory, rat GH cDNA (kindly supplied by Dr J A Martial, University of Liège, Belgium) and mouse $\beta$-actin cDNA (Ambion Inc., Austin, TX, USA) were radioisotopically labeled with $\alpha-{ }^{32} \mathrm{P}-\mathrm{dCTP}$ (3000 Ci/mmol; Amersham Pharmacia Biotech) by a random primer DNA labeling kit version 2.0 (Takara Shuzo Co. Ltd).

The membranes were hybridized at $43{ }^{\circ} \mathrm{C}$ for $16 \mathrm{~h}$ in a solution containing $5 \times \mathrm{SSPE}, 1 \times$ Denhardt's solution, $50 \%(\mathrm{v} / \mathrm{v})$ deionized formamide, $20 \mu \mathrm{g} / \mathrm{ml}$ denatured herring sperm DNA and labeled cDNA probe. The membranes were washed in $5 \times$ SSC and $0 \cdot 1 \%(\mathrm{w} / \mathrm{v})$ SDS and $1 \times$ SSC and $0.1 \%(\mathrm{w} / \mathrm{v}) \mathrm{SDS}$ at $45^{\circ} \mathrm{C}$ for $30 \mathrm{~min}$, followed by a final wash in $0 \cdot 1 \times$ SSC and $0 \cdot 1 \%(\mathrm{w} / \mathrm{v})$ SDS at $45^{\circ} \mathrm{C}$ for $30 \mathrm{~min}$. They were exposed to RX-U (Fuji medical X-ray film; Fuji Photo Film, Tokyo, Japan) at $-80{ }^{\circ} \mathrm{C}$ with double intensifying screens overnight. As an internal control, $\beta$-actin mRNA was detected with $\beta$-actin cDNA probe after the detection of GH or POMC mRNAs. The signal intensities were normalized relative to the intensity of $\beta$-actin mRNA.

\section{In situ hybridization}

GH receptor mRNA-expressing cells were detected by non-radioisotopic in situ hybridization as described previously (Honda et al. 1998). Pituitary glands were quickly fixed with $4 \%$ paraformaldehyde in $0.01 \mathrm{M}$ phosphatebuffered saline (PBS; pH 7.6) at $4{ }^{\circ} \mathrm{C}$ overnight. They were then embedded in paraffin, and sectioned at a thickness of $5 \mu \mathrm{m}$. The sections were digested with $10 \mathrm{mg} / \mathrm{ml}$ proteinase K (Merck, Darmstadt, Germany) at $37^{\circ} \mathrm{C}$ for $30 \mathrm{~min}$ and the reaction of proteinase $\mathrm{K}$ was blocked with $0 \cdot 2 \%(\mathrm{w} / \mathrm{v})$ glycine in $0.01 \mathrm{M}$ PBS. The sections were postfixed with $4 \%$ paraformaldehyde in $0 \cdot 01 \mathrm{M}$ PBS, and washed twice with PBS for $30 \mathrm{~s}$. Finally, the sections were incubated in $0 \cdot 25 \%$ acetic anhydride0.1 M triethanolamine for $10 \mathrm{~min}$ at room temperature. 
Preparation and detection of cDNA probes was carried out using a digoxigenin (DIG) DNA labeling and detection kit (Boehringer Mannheim, Mannheim, Germany). Mouse GHR cDNA (pmghr1-1) was labeled with DIG11-UTP by a random primer method at $37^{\circ} \mathrm{C}$ for $20 \mathrm{~h}$. pBR328 plasmids were labeled and used as a negative control for in situ hybridization. After the random-labeling reaction, DIG-labeled DNA probes were purified as follows. Twenty microliters labeling mixture were added to $2 \mu \mathrm{l} 5 \mathrm{M} \mathrm{LiCl}, 3 \mu \mathrm{l} 10 \mathrm{mg} / \mathrm{ml}$ herring sperm DNA and $75 \mu \mathrm{l}$ prechilled ethanol, and kept at $-80{ }^{\circ} \mathrm{C}$ for at least $30 \mathrm{~min}$, followed by centrifugation $\left(11000 \mathrm{~g}, \quad 4^{\circ} \mathrm{C}\right.$, $20 \mathrm{~min}$ ) to precipitate only the DIG-labeled DNA probes.

The pituitary sections were placed in a moist chamber and hybridized at $42{ }^{\circ} \mathrm{C}$ overnight in a solution containing $5 \times \mathrm{SSPE}, 1 \times$ Denhardt's solution, $10 \%(\mathrm{w} / \mathrm{v})$ sodium dextran sulfate, $50 \%(\mathrm{v} / \mathrm{v})$ deionized formamide, $120 \mu \mathrm{g} /$ $\mathrm{ml}$ denatured herring sperm DNA and $0.3 \mathrm{ng} / \mu \mathrm{l}$ DIGlabeled probe. The slides were washed in $1 \times \mathrm{SSC}$ at room temperature for $10 \mathrm{~min}$, then in $1 \times \mathrm{SSC}$ at $45^{\circ} \mathrm{C}$ for $15 \mathrm{~min}$, then in $0.5 \times \mathrm{SSC}$ at $45^{\circ} \mathrm{C}$ for $15 \mathrm{~min}$. The final wash was carried out in $0.2 \times$ SSC at room temperature for $3 \mathrm{~min}$. Non-specific binding was blocked with $0.5 \%$ $(\mathrm{w} / \mathrm{v})$ bovine serum albumin in TN buffer $(0 \cdot 1 \mathrm{M}$ Tris$\mathrm{HCl}, 0 \cdot 3 \mathrm{M} \mathrm{NaCl}, \mathrm{pH} 7 \cdot 5$ ) for $30 \mathrm{~min}$. Anti-DIG-alkaline phosphatase conjugate $(1: 1000)$ was applied to the sections at room temperature for $1 \mathrm{~h}$. The slides were washed three times with TN buffer containing 0.3\% Tween 20 for $10 \mathrm{~min}$. The hybridization signal was visualized using nitro blue tetrazolium and 5-bromo-4-chloro-3-indolyl phosphate as chromogens.

\section{Immunocytochemical analysis of $\mathrm{GH}$ receptor $m R N A$-expressing cells}

After the in situ hybridization analysis of GH receptor mRNA, the sections were immunocytochemically stained with one of the polyclonal antisera raised against anterior pituitary hormones: rabbit anti-pig ACTH (1:2000; Advance, Tokyo, Japan), rabbit anti-rat thyrotropin $\beta$ (TSH $\beta ; 1: 2000$, anti-r $\beta$ TSH-IC-1; NIDDK), guinea pig anti-rat luteinizing hormone $\beta$ (LH $\beta ; 1: 2500$; anti-r $\beta \mathrm{LH}-$ IC-2; NIDDK), guinea pig anti-rat follicle-stimulating hormone $\beta$ (FSH $\beta ; 1: 2000$, anti-r $\beta$ FSH-IC-1; NIDDK), rabbit anti-rat GH, (1:2000; Takahashi 1992), and rabbit anti-mouse prolactin (PRL; 1:2000; Shikibo, Kusatsu, Japan). The primary antibodies were localized with antirabbit $\operatorname{IgG}$, anti-monkey $\operatorname{IgG}$ or anti-guinea pig $\operatorname{IgG}$ fluorescein-labeled antisera for $30 \mathrm{~min}$. Immunostaining was abolished by omission of each primary antibody or by the use of primary antibodies (working dilution, $100 \mu \mathrm{l}$ ) preabsorbed with $10 \mu \mathrm{g}$ of each highly purified pituitary hormone (rat $\mathrm{GH}$, rat $\mathrm{PRL}$, rat $\mathrm{ACTH}$, rat $\mathrm{TSH}$, rat $\mathrm{LH}$, rat FSH respectively) at $4{ }^{\circ} \mathrm{C}$ for $24 \mathrm{~h}$. The specificity of antibodies to $\mathrm{GH}$ and PRL was also checked with the immunoblotting assay (Takahashi 1992). The pituitary cells were incubated with one of the antibodies to GH, PRL, ACTH or TSH $\beta$ at room temperature for $2 \mathrm{~h}$ or one of the antibodies to $\mathrm{LH} \beta$ or $\mathrm{FSH} \beta$ at $4{ }^{\circ} \mathrm{C}$ for $48 \mathrm{~h}$. The primary antibodies were localized with fluorescein-labeled antibodies (EY Laboratories, San Mateo, CA, USA).

\section{Statistical analysis}

Statistical significance of the difference between the means was assessed with one-way analysis of variance. Three independent experiments were performed in each study.

\section{Results}

\section{Competitive RT-PCR assay for IGF-I $m R N A$}

Aliquots of the RT products (equivalent to $0 \cdot 2,1 \cdot 0$ and $2 \cdot 0 \mu \mathrm{l}$ of the RT products) were subjected to PCR, and the amplifications were carried out with IGF-I competitors $\left(10^{5}\right.$ to $10^{6}$ copies) and $\beta$-actin competitors $\left(10^{7}\right.$ to $10^{8}$ copies). The ethidium bromide-stained gels were quantified, and the ratios of the band intensities of the PCR products from the RT products to the band intensities of the PCR products from the competitor template were calculated. We verified that the amount of PCR products increased in accordance with the increase in the amount of $\mathrm{RT}$ products used as the template for PCR in the determination of the mRNA levels of IGF-I and $\beta$-actin (data not shown). These results indicated that the competitive RT-PCR assay allowed us to semiquantitatively estimate the IGF-I and $\beta$-actin mRNA levels.

Effect of GH, ACTH, GHRH, DEX and E2 treatment on IGF-I $m R N A$ expression

IGF-I mRNA levels in the cultured cells were quantified using the competitive RT-PCR assay (Fig. 1). GH treatment $(1 \mu \mathrm{g} / \mathrm{ml})$ significantly increased IGF-I mRNA levels $2 \cdot 1$-fold over the control level $(P<0 \cdot 01)$. ACTH treatment $\left(10^{-8}\right.$ and $\left.10^{-7} \mathrm{M}\right)$ and GHRH treatment $\left(10^{-8}\right.$ and $\left.10^{-7} \mathrm{M}\right)$ did not change the IGF-I mRNA levels. DEX treatment $\left(10^{-7} \mathrm{M}\right)$ significantly decreased IGF-I mRNA levels $0 \cdot 8$-fold $(P<0 \cdot 05)$. Since E2 treatment is known to stimulate IGF-I expression in the mouse uterus, it was investigated. However, E2 treatment $\left(10^{-11}\right.$ and $\left.10^{-9} \mathrm{M}\right)$ did not change the IGF-I mRNA levels.

Effect of GH, IGF-I, ACTH, GHRH and DEX treatment on GH $m R N A$ expression

$\mathrm{GH}$ treatment $(0 \cdot 5$ and $1 \mu \mathrm{g} / \mathrm{ml})$ did not significantly change GH mRNA expression (Fig. 2). IGF-I treatment 
A

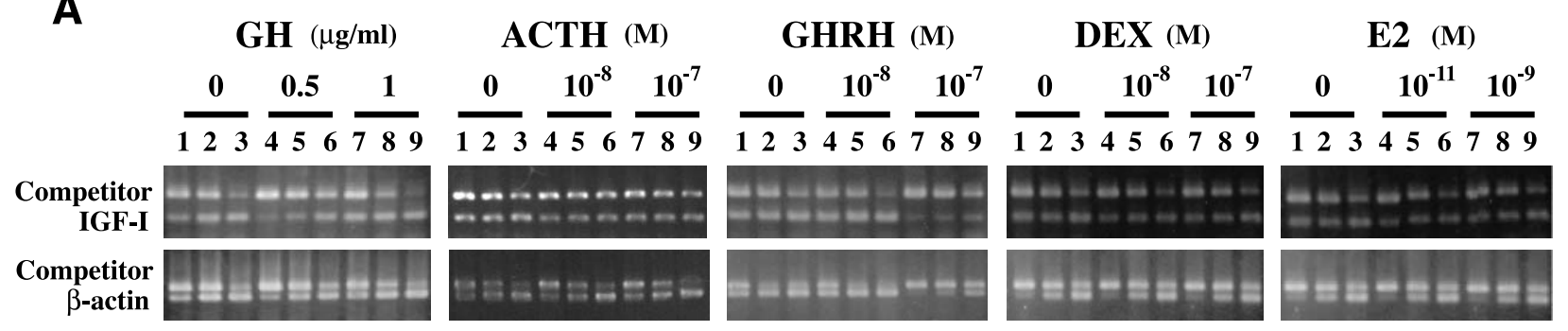

B

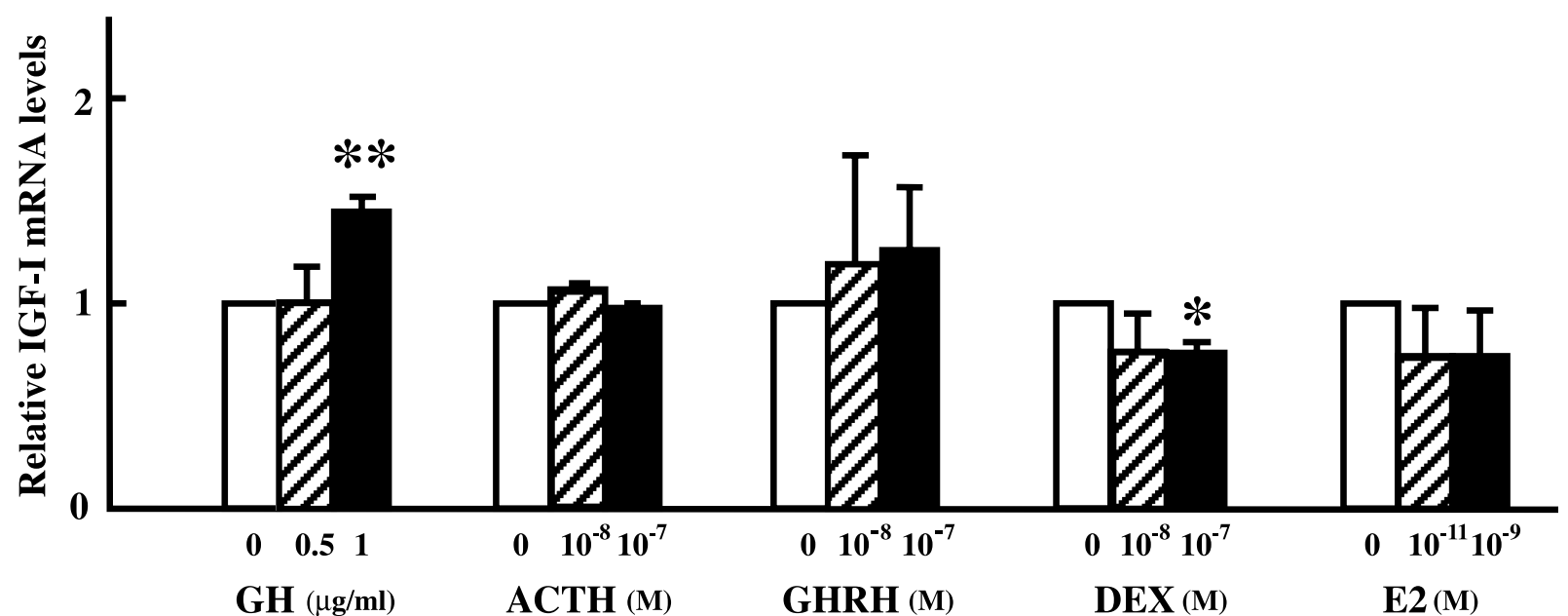

Figure 1 Effect of $\mathrm{GH}, \mathrm{ACTH}, \mathrm{GHRH}, \mathrm{DEX}$ and E2 treatment on IGF-I expression. Cultured pituitary cells were treated with GH $(0 \cdot 5$ and $1 \mathrm{\mu g} / \mathrm{ml}), \mathrm{ACTH}\left(10^{-8}\right.$ and $\left.10^{-7} \mathrm{M}\right), \mathrm{GHRH}\left(10^{-8}\right.$ and $\left.10^{-7} \mathrm{M}\right)$, DEX $\left(10^{-8}\right.$ and $\left.10^{-7} \mathrm{M}\right)$ and E2 $\left(10^{-11}\right.$ and $\left.10^{-9} \mathrm{M}\right)$ for $24 \mathrm{~h} . \mathrm{IGF}^{-\mathrm{I}}$ mRNA levels were measured by competitive RT-PCR. (A) Typical example of ethidium bromide-stained competitive RT-PCR products (upper panel, IGF-I; lower panel, $\beta$-actin). In each hormone treatment, $10^{6}$ or $10^{8}$ (lanes 1,4 and 7 ), $5 \times 10^{5}$ or $5 \times 10^{7}$ (lanes 2,5 and 8 ) and $10^{5}$ or $10^{7}$ copies (lanes 3,6 and 9) of IGF-I or $\beta$-actin competitors were used. (B) Summary of the competitive RT-PCR analysis of IGF-I mRNA levels. The values represent the relative levels of IGF-I mRNA compared with the level in control cells without hormone treatment which was defined as 1.0. IGF-I mRNA levels were normalized relative to the amount of $\beta$-actin mRNA. Each value is the mean \pm S.E.M. of three different preparations of RNA. ${ }^{*} P<0 \cdot 05,{ }^{*} P<0 \cdot 01$ compared with control.

$(7 \cdot 5$ and $75 \mathrm{ng} / \mathrm{ml})$ significantly decreased GH mRNA levels $0 \cdot 7$ - and $0 \cdot 5$-fold respectively $(P<0 \cdot 05$; Fig. 3). ACTH treatment did not change GH mRNA levels. GHRH treatment $\left(10^{-8}\right.$ and $\left.10^{-7} \mathrm{M}\right)$ significantly increased GH mRNA levels 1.3-fold over control levels at both concentrations $(P<0 \cdot 05)$. DEX treatment $\left(10^{-8}\right.$ and $\left.10^{-7} \mathrm{M}\right)$ did not change GH mRNA levels.

\section{Effect of IGF-I and GH treatment on POMC $m R N A$} expression

IGF-I treatment $(75 \mathrm{ng} / \mathrm{ml})$ for $24 \mathrm{~h}$ significantly increased POMC mRNA levels $1 \cdot 8$-fold $(P<0 \cdot 05)$, but treatment with a low concentration of IGF-I $(7.5 \mathrm{ng} / \mathrm{ml})$ did not change POMC expression (Fig. 4). GH treatment (4 and $8 \mu \mathrm{g} / \mathrm{ml}$ ) for 4 days significantly increased POMC mRNA levels $(P<0 \cdot 05$; Fig. 5$)$.
Northern blotting analysis of $G H$ receptor $m R N A$ and GH-binding protein (GHBP) $m R N A$

Using a cDNA probe (pmghr1-1) encoding the common extracellular domain of the GH receptor and the circulating GHBP, Northern blotting analysis revealed two bands $(1.4$ and $4.2 \mathrm{~kb})$ in the RNA samples obtained from the anterior pituitary glands of male mice (Fig. 6). The $1.4 \mathrm{~kb}$ band is considered to be GHBP mRNA and the $4.2 \mathrm{~kb}$ band is considered to be GH receptor mRNA.

In situ hybridization analysis of GH receptor $m R N A$-expressing cells

GH receptor mRNA in mouse pituitary glands was detected by non-radioisotopic in situ hybridization. GH receptor mRNA was expressed in a subpopulation of 


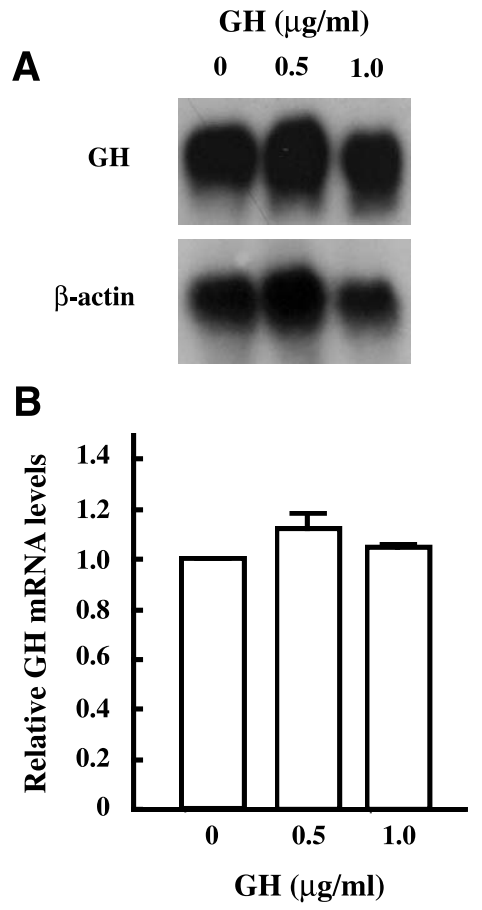

Figure 2 Effect of $\mathrm{GH}$ treatment on the expression of the $\mathrm{GH}$ gene in mouse pituitary cells in primary culture. (A) Autoradiogram of the results of a Northern blotting analysis of RNA prepared from pituitary cells treated with 0.5 or $1.0 \mu \mathrm{g}$ rat $\mathrm{GH}$ per well $(1 \mathrm{ml})$ for $24 \mathrm{~h}$. The upper band indicates GH mRNA, and the lower band indicates $\beta$-actin mRNA. (B) Summary of Northern blotting analysis of GH mRNA levels. The values represent the relative level of GH mRNA compared with the level in control cells without $\mathrm{GH}$ treatment which was defined as $1 \cdot 0$. In each sample, GH mRNA levels were normalized relative to the amount of $\beta$-actin mRNA. Each value is the mean \pm s.E.M. of three different preparations of RNA.

secretory cells in the anterior lobe (Fig. 7A). GH receptor mRNA was not detected in the intermediate and posterior lobes. The cells expressing GH receptor mRNA were round or oval in shape, medium-sized and accounted for approximately $50 \%$ of all anterior pituitary cells in the adult male mice (Fig. 7B). GH receptor mRNAexpressing cells were distributed throughout the anterior pituitary gland. In the control experiments for the in situ hybridization, no signal was detected with DIG-labeled pBR328 as the probe (Fig. 7C).

Characterization of $\mathrm{GH}$ receptor $m R N A$-expressing cells in the anterior pituitary

The anterior pituitary hormones produced in the GH receptor mRNA-expressing cells were determined immunocytochemically. The GH receptor mRNAexpressing cells contained immunoreactive GH (Fig. 8A and B). In some of the mammotrophs and FSH $\beta$ - immunoreactive gonadotrophs, $\mathrm{GH}$ receptor mRNA was detected
A

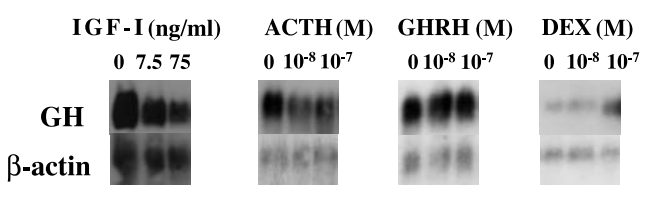

B

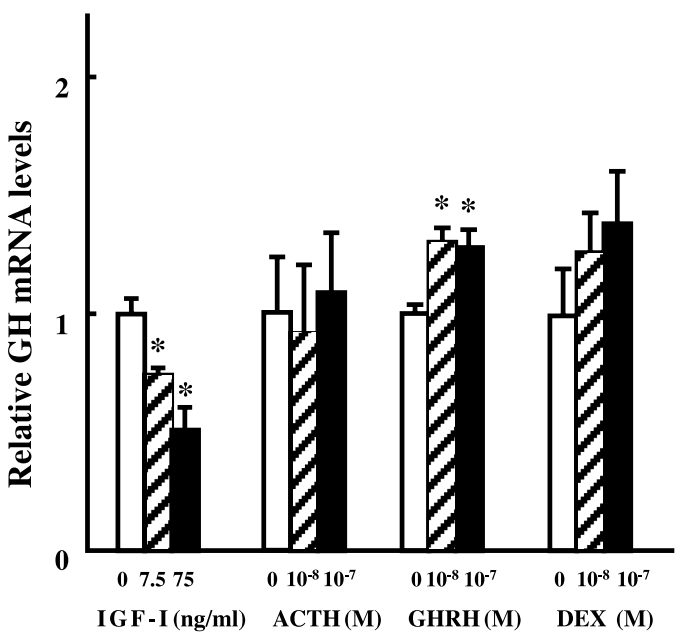

Figure 3 Effect of IGF-I, ACTH, GHRH and DEX treatment on GH gene in mouse pituitary cells in primary culture. (A) Autoradiogram of the results of a Northern blotting analysis of RNA prepared from pituitary cells treated with IGF-I, ACTH, GHRH and DEX for $24 \mathrm{~h}$. The upper band indicates GH mRNA, and the lower band indicates $\beta$-actin mRNA. (B) Summary of Northern blotting analysis of $\mathrm{GH}$ mRNA levels. The values represent the relative level of $\mathrm{GH}$ mRNA compared with the level in control cells without $\mathrm{GH}$ treatment which was defined as 1.0. In each sample, GH mRNA levels were normalized relative to the amount of $\beta$-actin mRNA. Each value is the mean \pm S.E.M. of three different preparations of RNA. ${ }^{*} P<0 \cdot 05$ compared with control.

(Fig. 8C and D, K and L). GH receptor mRNA was not detected in corticotrophs and gonadotrophs (Fig. 8E and F, $\mathrm{G}$ and $\mathrm{H}$, I and $\mathrm{J}$ ).

\section{Discussion}

Pituitary IGF-I exerts local actions to regulate pituitary functions within the gland, since IGF-I-binding sites (Goodyer et al. 1984b) and the mRNAs encoding the IGF-I receptor and binding proteins are found in the pituitary (Bach \& Bondy 1992). We have previously found expression of IGF-I receptor mRNA in mouse somatotrophs (Honda et al. 1998), and have shown the mitogenic action of IGF-I on corticotrophs and mammotrophs (Oomizu et al. 1998). In the present study, we have demonstrated that IGF-I suppressed GH synthesis and stimulated POMC synthesis at the transcription level. IGF-I treatment significantly decreased GH mRNA levels. These results are consistent with previous reports 
A

\section{IGF-I (ng/ml)}

$\begin{array}{lll}\text { o } & 7.5 & 75\end{array}$

POMC
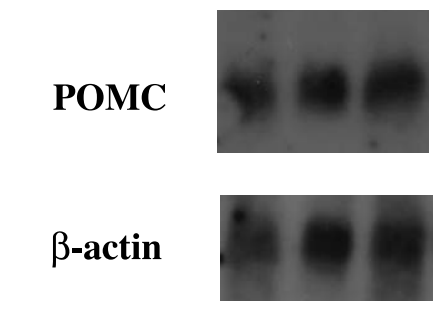

B

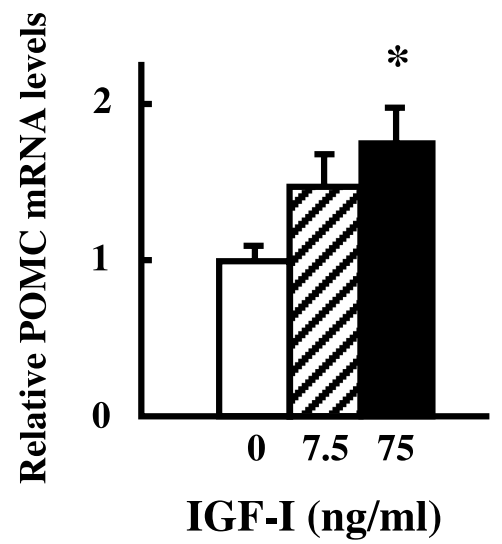

Figure 4 Effect of IGF-I treatment on POMC gene expression in mouse pituitary cells in primary culture. (A) Autoradiogram of the results of Northern blotting analysis of RNA prepared from pituitary cells treated with IGF-I for $24 \mathrm{~h}$. The upper band indicates POMC mRNA, and the lower band indicates $\beta$-actin mRNA.

(B) Summary of Northern blotting analysis of POMC mRNA levels. The values represent the relative level of POMC mRNA compared with the level in control cells without IGF-I treatment which was defined as $1 \cdot 0$. In each sample, POMC mRNA levels were normalized relative to the amount of $\beta$-actin mRNA. Each value is the mean \pm S.E.M. of three different preparations of RNA. ${ }^{*} P<0.05$ compared with control.

that IGF-I attenuates GH expression and secretion at the pituitary level (Goodyer et al. 1984a, Yamashita \& Melmed 1986, Ceda et al. 1987, Yamasaki et al. 1991). In addition, pituitary IGF-I gene transcription was enhanced by GH treatment, which was clarified using the competitive RT-PCR method. This is the first report showing direct evidence of GH-induced IGF-I synthesis in mouse pituitary cells as far as we know. Together, these results lead us to the hypothesis that pituitary IGF-I is an inhibitory mediator of $\mathrm{GH}$ for the regulation of $\mathrm{GH}$ gene expression, and a stimulatory mediator for POMC gene expression. It is probable that $\mathrm{GH}$ first stimulates IGF-I expression in somatotrophs in an autocrine manner and then, in turn, the elevated IGF-I level within the pituitary gland diminishes $\mathrm{GH}$ synthesis.
A

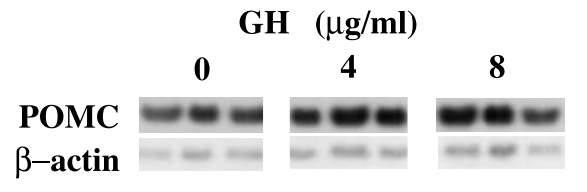

B

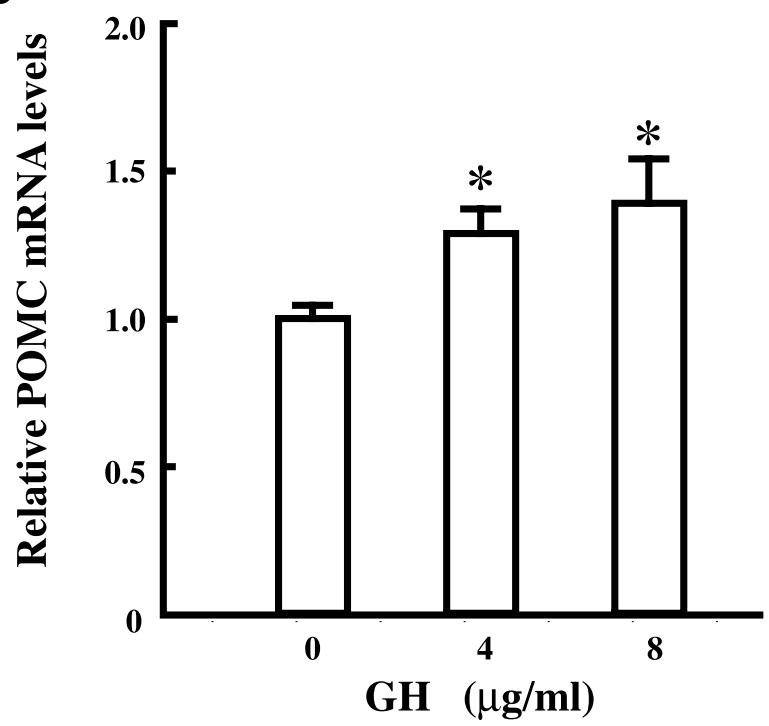

Figure 5 Effect of $\mathrm{GH}$ treatment on POMC gene expression in mouse pituitary cells in primary culture. (A) Autoradiogram of the results of a Northern blotting analysis of RNA prepared from pituitary cells treated with $\mathrm{GH}$ for 4 days. The upper band indicates $\mathrm{GH}$ mRNA, and the lower band indicates $\beta$-actin mRNA. (B) Summary of Northern blotting analysis of POMC mRNA levels. The values represent the relative level of POMC mRNA compared with the level in control cells without GH treatment which was defined as $1 \cdot 0$. In each sample, POMC mRNA levels were normalized relative to the amount of $\beta$-actin mRNA. Each value is the mean \pm S.E.M. of three different preparations of RNA. ${ }^{\star} P<0.05$ compared with control.

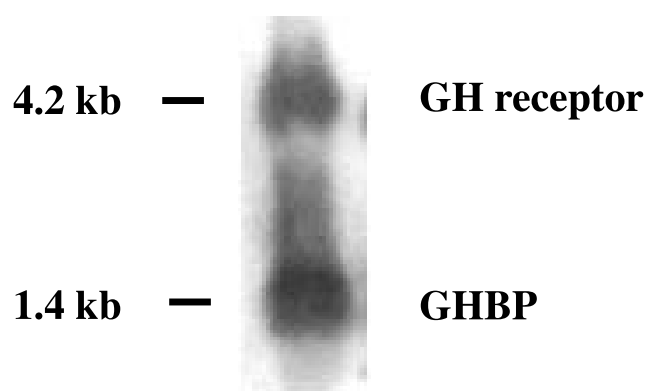

Figure 6 Northern blotting analysis of $\mathrm{GH}$ receptor mRNA in the mouse. Total RNA $(20 \mu \mathrm{g})$ derived from pituitaries was used. Mouse GH receptor cDNA probe was used. $4 \cdot 2 \mathrm{~kb}$ GH receptor mRNA and $1.4 \mathrm{~kb}$ GHBP mRNA were detected.

IGF-I is synthesized predominantly in the liver under the control of GH (Schwander et al. 1983, Lowe et al. 1987, Shoba et al. 2001), and acts as a mediator of the 


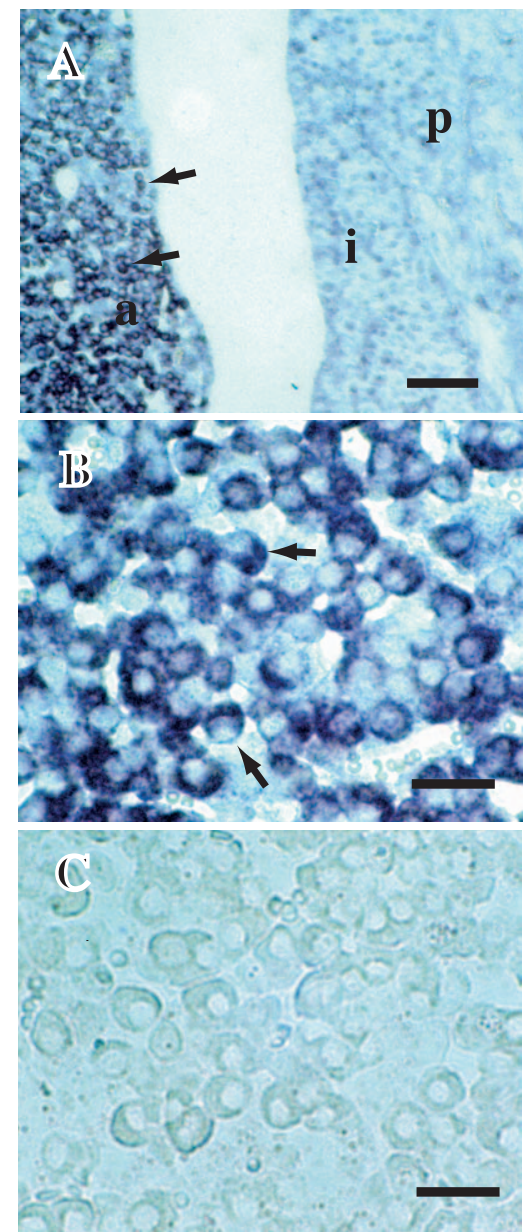

Figure 7 In situ hybridization analysis of GH receptor mRNA in mouse pituitary glands. (A) $\mathrm{GH}$ receptor mRNA-expressing cells (arrow) were detected in anterior lobe (a), but in the intermediate lobe (i) or posterior lobe (p), GH receptor mRNA-expressing cells were not detected. Bar $=50 \mu \mathrm{m}$. (B) GH receptor mRNAexpressing cells in anterior pituitary cells (arrow). Bar $=30 \mu \mathrm{m}$. (C) In situ hybridization using pBR328 as probe. No hybridization signals were detected. Bar $=30 \mu \mathrm{m}$.

growth-promoting actions of GH (LeRoith et al. 1995). The IGF-I gene is expressed in multiple extrahepatic tissues, including the pituitary gland (D'Ercole et al. 1984). Possible autocrine and paracrine actions of IGF-I have been recognized in the pituitary gland (Yamasaki et al. 1991, Bach \& Bondy 1992, Honda et al. 1998, Oomizu et al. 1998). We have investigated whether or not GH affected pituitary IGF-I synthesis in a similar manner to the hepatic IGF-I synthesis in mice. Treatment of mouse pituitary cells with $\mathrm{GH}$ at concentrations of 0.5 and $1 \mu \mathrm{g} / \mathrm{ml}$, which were chosen according to previous data on serum GH levels in mice (Sinha et al. 1977), were carried out, and we found that GH treatment increased IGF-I mRNA levels. Since somatotrophs are the source of pituitary IGF-I (Honda et al. 1998) and the expressed GH receptor mRNA, and probably the GH-receptor protein, as evidenced by the presence of GH-receptor mRNA transcripts in the present study, we have concluded that GH directly stimulates IGF-I gene expression through the $\mathrm{GH}$ receptor expressed on somatotrophs.

GHRH treatment significantly increased $\mathrm{GH}$ expression as expected, but did not have any significant effect on IGF-I synthesis, which is in agreement with a previous report that chronic administration of a potent agonist of GHRH did not change serum IGF-I levels (Kovács et al. 1996). These results indicate that pituitary IGF-I synthesis is not directly regulated by hypothalamic GHRH.

Estrogen is known to be a stimulator of IGF-I expression in the pituitaries of ovariectomized and estrous rats (Michels et al. 1993). However, E2 treatment failed to stimulate IGF-I expression in the mouse pituitary. These discrepancies may be due to differences in the animal species and/or the sex used, and/or the experimental schedules. In our in vitro study, the steroid treatment was continued for only $24 \mathrm{~h}$, whereas Michels et al. (1993), for example, implanted pellets containing E2 for 54 days in vivo. Up-regulation of IGF-I transcription in the pituitary glands probably requires such chronic treatment with E2.

Several previous reports have shown that exogenous GH treatment caused suppression of the endogenous pulsatile GH secretion in rats (Tannenbaum 1980, Willoughby et al. 1980). Considering these previous findings, we studied the effect of $\mathrm{GH}$ on $\mathrm{GH}$ synthesis. $\mathrm{GH}$ treatment did not change the GH mRNA levels. A similar result for cultured rat anterior pituitary cells showing that $\mathrm{GH}$ treatment (200 and $1000 \mathrm{ng} / \mathrm{ml}$ ) for 1 day did not inhibit GH release has been reported (Goodyer et al. 1984a). These results suggest that GH expression is not regulated by the direct action of $\mathrm{GH}$ in mice, and this is in agreement with previous studies performed in rats that $\mathrm{GH}$ autoregulates its own secretion in the hypothalamus, but not in the pituitary (Richman et al. 1981, Kraicer et al. 1988).

IGF-I is synthesized in various areas of the brain, including the hypothalamus (García-Segura et al. 1991, Dueñas et al. 1994), and IGF-I receptors are also present in the brain (Werther et al. 1990, Kar et al. 1993). Several reports have indicated that IGF-I also takes part in the regulation of $\mathrm{GH}$ secretion in the hypothalamus (Tannenbaum et al. 1983, Yamashita \& Melmed 1986). However, it is not clear whether circulating IGF-I or IGF-I synthesized in the brain affects GHRH and somatostatin release from the hypothalamus. From the findings in the present study, we have concluded that IGF-I regulates $\mathrm{GH}$ synthesis at the pituitary level as well as at the hypothalamic level.

The expression of POMC mRNA was stimulated by IGF-I treatment. However, Goodyer et al. (1984a) reported that the release of $\mathrm{ACTH}$, one of the POMC-derived peptides, remained unaltered with IGF-I treatment. This 

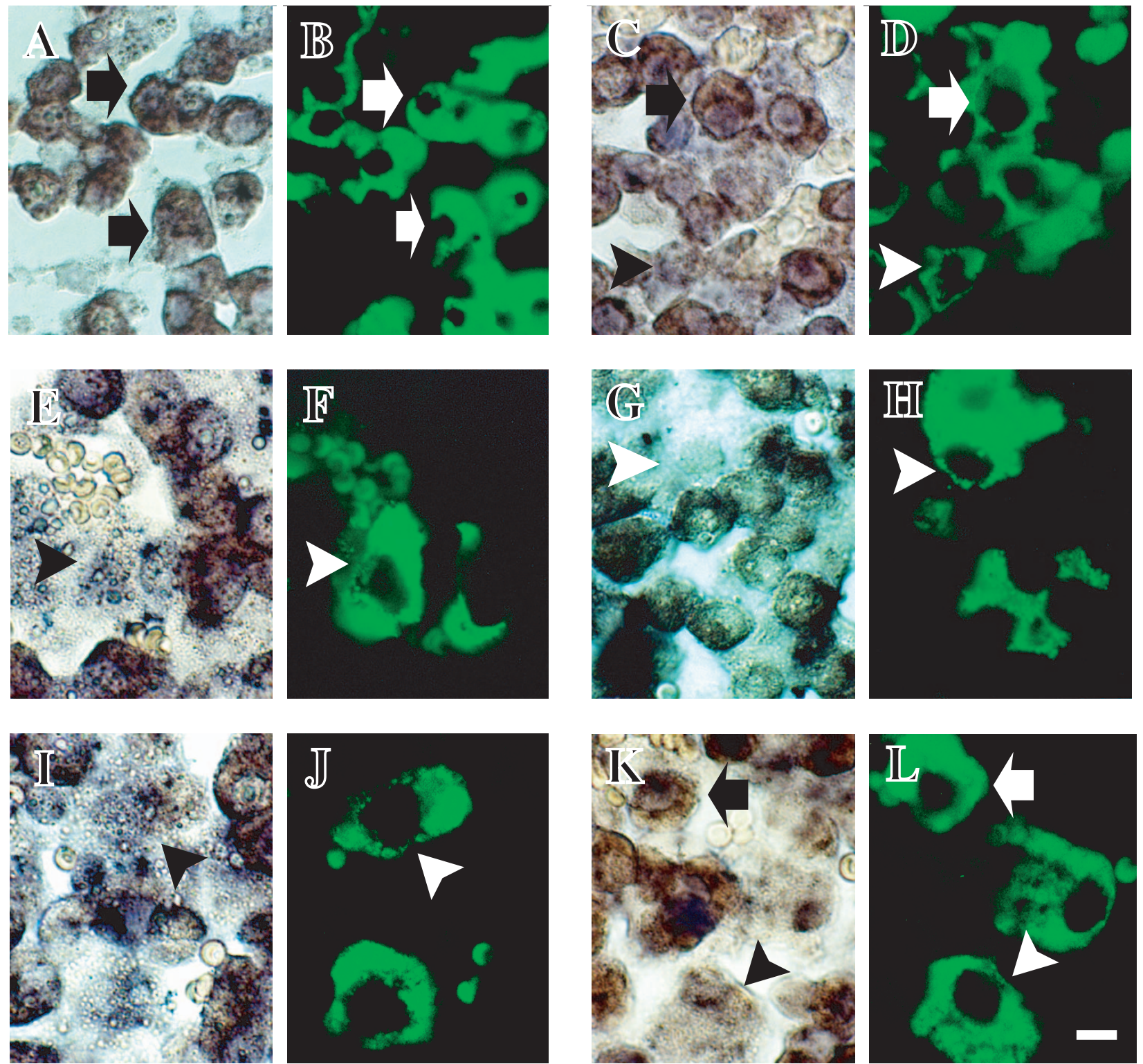

Figure 8 Analysis of cell types of $\mathrm{GH}$ receptor mRNA-expressing cells. In situ hybridization detection of GH receptor mRNA (A, C, E, G, I and $\mathrm{K}$ ) and immunocytochemical detection of $\mathrm{GH}(\mathrm{B}), \mathrm{PRL}(\mathrm{D}), \mathrm{ACTH}(\mathrm{F}), \mathrm{TSH} \beta(\mathrm{H}), \mathrm{LH} \beta(\mathrm{J})$ and FSH $\beta(\mathrm{L})$ were simultaneously carried out. $A$ and $B, C$ and $D, E$ and $F, G$ and $H, I$ and $J$, and $K$ and $L$ are the same sections respectively. A GH-immunoreactive cell (B, arrow) expressed $\mathrm{GH}$ receptor mRNA (A, arrow). A PRL-immunoreactive cell (D, arrow) and an FSH $\beta$-immunoreactive cell ( $\mathrm{L}$, arrow) expressed $\mathrm{GH}$ receptor mRNA ( $\mathrm{C}$ and $\mathrm{K}$, arrows). However, other PRL-immunoreactive cells ( $\mathrm{D}$, arrowhead) and FSH $\beta$-immunoreactive cells (L, arrowhead) did not express $\mathrm{GH}$ receptor mRNA (C and K, arrowheads). ACTH (E and F)-, TSH $\beta$ (G and H)- and LH $\beta$ (I and J)-immunoreactive cells did not express GH receptor mRNA (arrowheads). Bar $=10 \mu \mathrm{m}$.

discrepancy remains to be clarified, but may be ascribed to post-transcriptional inhibition of POMC expression by the accumulation of POMC mRNA. As some corticotrophs express IGF-I receptor mRNA (Honda et al. 1998), the present findings lead us to the conclusion that pituitary IGF-I acts directly on the corticotrophs, and stimulates POMC gene expression in a paracrine manner in the mouse pituitary gland. POMC gene expression in corticotrophs appears to be regulated co-ordinately by two factors, hypothalamic corticotropin-releasing hormone and pituitary IGF-I.

A 4-day exposure to rat $\mathrm{GH}(4$ and $8 \mu \mathrm{g} / \mathrm{ml})$ significantly increased the POMC mRNA levels. We estimated that these concentrations of GH correspond to approximately $10^{-7} \mathrm{M}$, although we had no information about the purity of the GH preparation used. The stimulatory 
effect of GH on POMC mRNA production appears to be indirect, since GH receptor mRNA signals were not detected in corticotrophs. Therefore, it is probable that $\mathrm{GH}$-induced POMC mRNA production is mediated by factors such as IGF-I whose synthesis is stimulated by GH.

The hypothalamo-corticotroph-adrenal axis has been extensively investigated with respect to the stress response, and energy and electrolyte metabolism. Activation of the hypothalamo-corticotroph-adrenal axis partially antagonizes the somatic growth regulated by the hypothalamosomatotroph-IGF-I axis. Glucocorticoids, e.g. DEX, are potent inhibitors of linear growth and GH secretion when secreted or administered in pharmacological amounts in vivo (Luo \& Murphy 1989, Ohyama et al. 1997). DEX inhibited GHRH expression in the hypothalamus, but increased GH expression (Evans et al. 1982, Lam \& Srivastava 1997). Treatment of mouse pituitary cells with DEX decreased IGF-I mRNA levels, and this is consistent with previous reports showing that DEX exerted potent inhibitory effects on IGF-I production in many types of cells (Luo \& Murphy 1989, Delany \& Canalis 1995). This seems to represent the negative feedback loop of glucocorticoid secretion, since pituitary IGF-I stimulates POMC gene expression in a paracrine manner, probably resulting in the enhanced production of ACTH. These findings provide the hypothesis that somatotrophs directly regulate corticotroph functions with IGF-I molecules, and that corticotrophs indirectly regulate somatotrophs being mediated by glucocorticoids. The somatotrophcorticotroph interaction at the pituitary level is implicated in the co-ordination of the stress response and regulation of somatic growth.

The present study has demonstrated the expression of GH receptor mRNA in the mouse anterior pituitary with RT-PCR. Northern blotting analysis using the mouse GH receptor cDNA probe (pmghr1-1) demonstrated two transcripts, the $4.2 \mathrm{~kb} G H$ receptor mRNA, and the $1.4 \mathrm{~kb}$ GHBP mRNA. This indicates that the mouse GH receptor cDNA probe used in the present study bound to both GH receptor mRNA and GHBP mRNA. Therefore, the GH receptor cDNA probe cannot differentiate $\mathrm{GH}$ receptor mRNA from GHBP mRNA. GH receptor mRNA and protein were detected in somatotrophs and non-GH-secreting cells (Fraser et al. 1991). These results are in agreement with the present finding that both $\mathrm{GH}$ receptor mRNA and GHBP mRNA were detected in mouse anterior pituitary glands, particularly in somatotrophs and some of the mammotrophs and gonadotrophs, while Ilkbahar et al. (1995) failed to find GH receptor mRNA expression in the mouse pituitary. The reason for this discrepancy is not clear. However, the in vitro physiological evidence of GH-induced IGF-I synthesis strongly indicates the expression of $\mathrm{GH}$ receptor in somatotrophs. GHBP within the cytoplasm of the anterior pituitary cells may have a role in modulating $\mathrm{GH}$ metabolism and $\mathrm{GH}$ action (Herington et al. 1991). GHBP stabilizes stored GH within somatotrophs and is co-secreted with GH molecules into the blood. Thus, GHBP regulates the number of GH molecules around the receptor site. From these observations, it is very likely that $\mathrm{GH}$ receptor and GHBP synthesized in pituitary glands regulate the functions of somatotrophs in an autocrine and/or paracrine manner.

Many lines of evidence have shown that a cell-to-cell interaction between pituitary secretory cells is important in the regulation of the proliferation and functions of pituitary cells, and that this interaction is mediated by hormones, growth factors and cytokines synthesized in the pituitary cells (Renner et al. 1996, Ray \& Melmed 1997, Schwartz 2000). In the present study, we have demonstrated that GH stimulated IGF-I synthesis in somatotrophs, and that IGF-I inhibited GH expression and stimulated POMC expression in corticotrophs. These findings suggest the presence of autocrine and paracrine actions of somatotrophic IGF-I within the pituitary gland, and a possible interaction between somatotrophs and corticotrophs.

\section{Acknowledgements}

The authors would like to thank the National Hormone and Pituitary Program, NIDDK, NIH, Bethesda, MD, USA for the kind supply of antibodies to pituitary hormones and purified pituitary hormones, and Dr J A Martial for generously supplying the rat GH cDNA probe. This study was supported in part by a Grant-in-Aid for Scientific Research from Japan Society for the Promotion of Science to S T.

\section{References}

Abe H, Molitch ME, Van Wyk J \& Underwood LE 1983 Human growth hormone and somatomedin $\mathrm{C}$ suppress the spontaneous release of growth hormone in unanesthetized rats. Endocrinology 113 1319-1324.

Bach MA \& Bondy CA 1992 Anatomy of the pituitary insulin-like growth factor system. Endocrinology 131 2588-2594.

Ceda GP, Davis RG, Rosenfeld RG \& Hoffman AR 1987 The growth hormone (GH)-releasing hormone (GHRH)-GHsomatomedin axis: evidence for rapid inhibition of GHRH-elicited $\mathrm{GH}$ release by insulin-like growth factor I and II. Endocrinology 120 $1658-1662$.

Chesnokova V \& Melmed S 2000 Leukemia inhibitory factor mediates the hypothalamic pituitary adrenal axis response to inflammation. Endocrinology 141 4032-4040.

Chomczynski P \& Sacchi N 1987 Single-step method of RNA isolation by acid guanidinium thiocyanate-phenol-chloroform extraction. Analytical Biochemistry 162 156-159.

Delany AM \& Canalis E 1995 Transcriptional repression of insulin-like growth factor I by glucocorticoids in rat bone cells. Endocrinology 136 4776-4781.

D’Ercole AJ, Stiles AD \& Underwood LE 1984 Tissue concentrations of somatomedin C: further evidence for multiple sites of synthesis and paracrine or autocrine mechanism of action. PNAS $\mathbf{8 1}$ 935-939.

Dueñas M, Luquin S, Chowen JA, Torres-Alemán I, Naftolin F \& Garcia-Segura LM 1994 Gonadal hormone regulation of insulin-like growth factor-I-like immunoreactivity in hypothalamic astroglia of developing and adult rats. Neuroendocrinology 59 528-538. 
Evans RM, Birnberg NC \& Rosenfeld MG 1982 Glucocorticoid and thyroid hormones transcriptionally regulate growth hormone gene expression. PNAS 79 7659-7663.

Fagin JA, Brown A \& Melmed S 1988 Regulation of pituitary insulin-like growth factor-I messenger ribonucleic acid levels in rats harboring somatomammotropic tumors: implications for growth hormone autoregulation. Endocrinology 122 2204-2210.

Fagin JA, Fernandez-Mejia C \& Melmed S 1989 Pituitary insulin-like growth factor-I gene expression: regulation by triiodothyronine and growth hormone. Endocrinology 125 2385-2391.

Fan X, Nagle GT, Collins TJ \& Childs GV 1995 Differential regulation of epidermal growth factor and transforming growth factor- $\alpha$ messenger ribonucleic acid in the rat anterior pituitary and hypothalamus induced by stresses. Endocrinology 136 873-880.

Fiorentini C, Guerra N, Facchetti M, Finardi A, Tiberio L, Schiaffonati L, Spano P \& Missale C 2002 Nerve growth factor regulates dopamine $\mathrm{D}(2)$ receptor expression in prolactinoma cell lines via $\mathrm{p} 75$ (NGFR)-mediated activation of nuclear factor-kappaB. Molecular Endocrinology 16 353-366.

Fraser RA, Siminoski K \& Harvey S 1991 Growth hormone receptor gene: novel expression in pituitary tissue. Journal of Endocrinology 128 R9-R11.

García-Segura LM, Pérez J, Pons S, Rejas MT \& Torres-Alemán I 1991 Localization of insulin-like growth factor I (IGF-I)-like immunoreactivity in the developing and adult rat brain. Brain Research 560 167-174.

Gonzalez-Parra S, Argente J, Chowen JA, van Kleffens M, van Neck JW, Lindenbeigh-Kortleve DJ \& Drop SL 2001 Gene expression of the insulin-like growth factor system during postnatal development of the rat pituitary gland. Journal of Neuroendocrinology 13 86-93.

Goodyer CG, de Stéphano L, Guyda HJ \& Posner BI 1984a Effects of insulin-like growth factors on adult male rat pituitary function in tissue culture. Endocrinology 115 1568-1576.

Goodyer CG, de Stéphano L, Lai W, Hsien, Guyda HJ \& Posner BI $1984 b$ Characterization of insulin-like growth factor receptors in rat anterior pituitary, hypothalamus, and brain. Endocrinology 114 $1187-1195$

Herington AC, Ymer SI \& Tiong TS 1991 Does the serum binding protein for growth hormone have a functional role? Acta Endocrinologica 124 14-20.

Ho Y, Wigglesworth K, Eppig JJ \& Shultz RM 1995 Preimplantation development of mouse embryos in KSOM: augmentation by amino acids and analysis of gene expression. Molecular Reproduction and Development 41 232-238.

Honda J, Takeuchi S, Fukamachi H \& Takahashi S 1998 Insulin-like growth factor-I and its receptor in mouse pituitary glands. Zoological Science 15 573-579.

Ilkbahar YN, Wu K, Thordarson G \& Talamantes F 1995 Expression and distribution of messenger ribonucleic acids for growth hormone $(\mathrm{GH})$ receptor and $\mathrm{GH}-$ binding protein in mice during pregnancy. Endocrinology 136 386-392.

Kar S, Chabot J-G \& Quirion R 1993 Quantitative autoradiographic localization of $\left[{ }^{125} \mathrm{I}\right]$ insulin-like growth factor I, $\left[{ }^{125} \mathrm{I}\right]$ insulin-like growth factor II, and $\left[{ }^{125} \mathrm{I}\right]$ insulin receptor binding sites in developing and adult rat brain. Journal of Comparative Neurology 333 375-397.

Kirk SE, Dalkin AC, Yasin M, Haisenleder DJ \& Marshall JC 1994 Gonadotropin-releasing hormone pulse frequency regulates expression of pituitary follistatin messenger ribonucleic acid: a mechanism for differential gonadotrope function. Endocrinology 135 876-880.

Kovács M, Halmos G, Groot K, Izdebski J \& Schally AV 1996 Chronic administration of a new potent agonist of growth hormone-releasing hormone induces compensatory linear growth in growth hormone-deficient rats: mechanism of action. Neuroendocrinology 64 169-176.
Kraicer J, Lussier B, Moor BC \& Cowan JS 1988 Failure of growth hormone $(\mathrm{GH})$ to feed back at the level of the pituitary to alter the response of the somatotrophs to GH-releasing factor. Endocrinology 122 1511-1514.

Lam KSL \& Srivastava G 1997 Gene expression of hypothalamic somatostatin and growth hormone-releasing hormone in dexamethasone-treated rats. Neuroendocrinology 66 2-8.

LeRoith D, Werner H, Beitner-Johnson D \& Roberts CT Jr 1995 Molecular and cellular aspects of the insulin-like growth factor I receptors. Endocrine Reviews 16 143-163.

Lowe WL Jr, Roberts CT Jr, Lasky SR \& LeRoith D 1987 Differential expression of alternative $5^{\prime}$ untranslated regions in mRNAs encoding rat insulin-like growth factor I. PNAS $\mathbf{8 4}$ 8946-8950.

Luo J \& Murphy LJ 1989 Dexamethasone inhibits growth hormone induction of insulin-like growth factor-I (IGF-I) messenger ribonucleic acid (mRNA) in hypophysectomized rats and reduces IGF-I mRNA abundance in the intact rat. Endocrinology 125 165-171.

Matsuda M \& Mori T 1997 Effect of hormones on expression of prolactin receptor messenger ribonucleic acids in pancreatic islets of adult female mice in vitro. Zoological Science 14 159-165.

Michels KM, Lee W-H, Seltzer A, Saavedra JM \& Bondy CA 1993 Up-regulation of pituitary $\left[{ }^{125} \mathrm{I}\right]$ insulin-like growth factor-I (IGF-I) binding and IGF binding protein-2 and IGF-I gene expression by estrogen. Endocrinology 132 23-29.

Ohyama T, Sato M, Niimi M, Hizuka N \& Takahara J 1997 Effects of short- and long-term dexamethasone treatment on growth and growth hormone $(\mathrm{GH})$-releasing hormone (GRH)-GH-insulin-like growth factor-I axis in conscious rats. Endocrine Journal 44 827-835.

Oomizu S, Takeuchi S \& Takahashi S 1998 Stimulatory effect of insulin-like growth factor I on proliferation of mouse pituitary cells in serum-free culture. Journal of Endocrinology 157 53-62.

Ray D \& Melmed S 1997 Pituitary cytokine and growth factor expression and action. Endocrine Reviews 18 206-228.

Renner U, Pagotto U, Arzt E \& Stalla GK 1996 Autocrine and paracrine roles of polypeptide growth factors, cytokines and vasogenic substances in normal and tumors pituitary function and growth: a review. European Journal of Endocrinology 135 515-532.

Richman R, Weiss JP, Hochberg Z \& Florini JR 1981 Regulation of growth hormone release: evidence against negative feedback in rat pituitary cells. Endocrinology 108 2287-2292.

Schwander JC, Hauri C, Zapf J \& Froesch ER 1983 Synthesis and secretion of insulin-like growth factor and its binding protein by the perfused rat liver: dependence on growth hormone status. Endocrinology 113 297-305.

Schwartz J 2000 Intercellular communication in the anterior pituitary. Endocrine Reviews 21 488-513.

Shoba LN, Newman M, Liu W \& Lowe WL Jr 2001 LY 294002, an inhibitor of phosphatidylinositol 3-kinase, inhibits GH-mediated expression of the IGF-I gene in rat hepatocytes. Endocrinology 142 3980-3986.

Sinha YN, Salocks CB, Wickes MA \& Vanderlaan WP 1977 Serum and pituitary concentrations of prolactin and growth hormone in mice during a twenty-four hour period. Endocrinology 100 786-791.

Smith WC, Colosi P \& Talamantes F 1988 Isolation of two molecular weight variants of the mouse growth hormone receptor. Molecular Endocrinology 2 108-116.

Takahashi S 1992 Growth hormone secretion in old female rats analyzed by the reverse hemolytic plaque assay. Acta Endocrinologica 127 531-535.

Takeuchi S, Yamamoto H \& Takeuchi T 1988 Expression of tyrosinase gene in amelanotic mutant mice. Biochemical and Biophysical Research Communications 155 470-475.

Tannenbaum GS 1980 Evidence for autoregulation of growth hormone secretion via the central nervous system. Endocrinology 107 $2117-2120$. 
Tannenbaum GS, Guyda HJ \& Posner BI 1983 Insulin-like growth factors: a role in growth hormone negative feedback and body weight regulation via brain. Science 220 77-79.

Werther GA, Abate M, Hogg A, Cheesman H, Oldfield B, Hards D, Hudson P, Power B, Freed K \& Herington AC 1990 Localization of insulin-like growth factor-I mRNA in rat brain by in situ hybridization - relationship to IGF-I receptors. Molecular Endocrinology 4 773-778.

Willoughby JO, Menadue M, Zeegers P, Wise PH \& Oliver JR 1980 Effects of human growth hormone on the secretion of rat growth hormone. Journal of Endocrinology 86 165-169.
Yamasaki H, Prager D, Gebremedhin S, Moise L \& Melmed S 1991 Binding and action of insulin-like growth factor I in pituitary tumor cells. Endocrinology 128 857-862.

Yamashita S \& Melmed S 1986 Insulin-like growth factor I action on rat anterior pituitary cells: suppression of growth hormone secretion and messenger ribonucleic acid levels. Endocrinology 118 176-182.

Received 1 April 2003

Accepted 4 April 2003 